\title{
Considerações sobre a Música e sua Práxis
}

\author{
Enio Squeff
}

\author{
"No princípio era o Verbo \\ e o Verbo estava em Deus \\ e o Verbo era Deus... \\ e o Verbo se fez carne." \\ (Evangelho, segundo S. João)
}

Pensar a música como expressão do mundo é tema antigo: ao que consta, Pitágoras (de quem só se conhece o que dele disseram seus discípulos) insistia na idéia de um mundo regulado pela harmonia musical. A racionalidade estaria no âmago do cosmos, assim como se podia inferir da teoria dos harmônicos. A idéia, pois, não é sequer moderna; mas aparece como uma das mais controvertidas, e por uma razão que nem sempre parece ter sido levada na devida conta: a natureza da música em face de seu próprio ser. Refiro-me à música enquanto práxis.

Na definição clássica de que a música é uma arte "temporal", tem-se um corolário instigante: ao se apresentar enquanto tempo, a música se propõe sempre como ação. Aduziria que é da essência da música ser práxis, já que ela só existe enquanto é. Nada contra a partitura, evidentemente: de todas as civilizações conhecidas, a cristã e ocidental parece ter se firmado realmente sob o signo de Gutenberg: a tradição ágrafa acabou soterrada bem antes da reprodutibilidade do livro, isso é verdade. Mas nada indicava a premência das partituras antes do advento da imprensa; é uma questão a ser discutida. Vem daí porém que, ao contrário, por exemplo, da pintura, que pré-existe em sua realidade ao ser apreciada por um espectador (o mesmo que lhe dá vida, ou movimento), a música só se realiza em sendo enquanto se faz (e não enquanto se faz partitura). Neste sentido, a música só existe e se expressa, como tal, desde que se realize como música, enquanto é práxis; vale dizer, enquanto acontece. Em música, teoria e práxis só existem, em sendo uma e outra, concomitantemente, como momentos integrados. É possível, pois, conceituar a música a posteriori, depois de sua passagem; pode-se, inclusive, defini-la de diversas maneiras mas a música tem um tempo que é só seu, que é ela própria e que é da sua essência; e que só se faz na sua realização, no seu devir. É um "fluir" que só é quando "se musicaliza"; quando se faz música. Recorrendo a um paradigma talvez impróprio, poder-se-ia mesmo projetá-la como uma espécie sui generis de "bola de fogo", aquela do físico César Lattes; ou seja, ela se faz sob a forma de chispa, no instante mesmo em que sua existência só pode ser constatada por momentos.

Não importa, sob este aspecto e a rigor, que tais momentos tenham a duração de quase duas horas, como uma sinfonia de Mahler; ou que seja a quase centelha do Ich will meine seele tauchen, do "Diechterliebe", de Schumann; ou que se faça ainda como qualquer das obras de Webern. É na fugacidade musical que a música se faz tal. Seu tempo determina sua existência, seu ser; seu tempo, aliás, é sua única realidade. E só existe enquanto alguém a constrói, pois não se concebe uma música que se teorize fora da realidade do tempo da sua interpretação. Música encerra- 
da em bulas, para ser "lida" - pode ser um poema ou algo pejado de teatralidade poética ou mesmo de "musicalidade" (para usar uma expressão da literatura); não é, porém, e nunca o será, música.

Ora, tal assertiva está longe de ser irrelevante. Importa não apenas para caracterizar a música enquanto atividade que se faz na práxis pura, como principalmente nas conseqüências que essa práxis redunda para os intérpretes ou para seus ouvintes (pois todos nós fazemos música enquanto a escutamos); no mais, porém, é relevante também e sobretudo para a questão em si, isto é, de que a música seja e faça história. Que não seja, pois, apenas a sua conseqüência ou seu apêndice.

Quanto ao primeiro aspecto - essa ação que resulta em sons sem o quê, nem porquê (digamos que isso num primeiro momento realmente seja possível), fico nele para constatar que, no Brasil, ou em outros países em que se pratica a assim chamada música sinfônica, as deficiências das orquestras e de seus intérpretes remetem quase sempre à práxis, e não por suas virtudes, mas por suas mazelas. Nos acidentes do fluir musical, a música se revela como um ato vivo que só existe enquanto se faz e é som.

Explica-se. Nos concertos e recitais ao vivo, isso se expressa para muito além da possibilidade de que pensemos a música como um desenrolar que pode ser interrompido. Adorno observou em seu estudo sobre Mahler que nada era tão enfadonhamente comprido quanto uma sinfonia daquele compositor devidamente cortada: a extirpação de certos trechos determinaria o encompridamento psicológico de um processo coeso como seria uma sinfonia de Mahler. Nada indica que não seja exatamente assim. Evidentemente certos acidentes incomodam e é compreensível que isso ocorra. A "boa interpretação" interessa a todos. Mas, de certa forma, os erros, paradoxalmente, não deixam de se constituir-também numa espécie de "pecado bendito" (era assim que se referia Santo Agostinho à traição de Judas; ao concluir que Cristo não existiria sem o pecado e sem o traidor, o Santo alcançava o paradoxo de saudar a ambos como co-responsáveis pela Salvação). Valha a menção para a conclusão de que a música, desde que bem feita, talvez não suscitasse de forma tão clara: falo dessa idéia da "temporalidade" de qualquer peça musical.

De fato, a "efemeridade" da música parece estar realmente mais exposta na sua interrupção do que na sua continuidade. Ou seja, sem fazer a apologia da incompetência, parece-me evidente que na eventualidade do curso da música, o lugar do erro, da desafinação ou do ritmo desgarrado seriam o momento de reflexão e de reversão. Nós a saberíamos como práxis por sua interrupção e não por sua continuidade. Não há como fugir dessa constatação; só que não há também como ir adiante sem tentar essa gênese da música a propósito do tempo.

Aqui a pergunta parece ser uma só: é possível pensar a música sem refletir sobre o tempo? Tudo indica que não, pois deveríamos acrescentar que talvez a música seja a única forma expressiva, esteticamente aceitável, de organização, digamos, "poética" do tempo. Parece ser assim, de fato: na organização de uma peça teatral, na sua ação, na cena ou no recital de poesias (que é teatro, encenação, não faz parte essencial da natureza da poesia), tudo se faz e se cria como tempo e em situações que so podem ser concebidas dentro dele. Rigorosamente e, sob este prisma, tudo é tempo. Mas na đimensão da música - e penso na música como tal, não na literatura imbricada nos dramas em música; ou na ópera - o tempo aparece preenchido por algo que o substancializa numa série de eventos e que só existe como mú- 
sica enquanto se faz como tal. Poder-se-ia acrescentar que o tempo, ele próprio, só aparece como tempo também pela música que o substantiva, ou seja, por uma série de eventos que são preenchimentos de momentos através de uma sucessão de ritmos e sons que existem enquanto se fazem quetais: seja num plano em que as notas se encadeiam de forma mais ou menos lógica (como acontece no sistema tonal, quando a memoria retém o processo da música, o seu "argumento"); seja na música aleatoria, quando o tempo é preenchido por notas que emergem numa relação de sucessóes deliberadamente "incoerentes" (ainda que necessariamente postos numa certa lógica, já que é impossível pensar numa memoria "não lógica", ou numa "não-memoria"). Nesta perspectiva, entretanto, a música faz do tempo o que ele não tem em si; pelo contrário, ela o dimensiona numa periodicidade específica, muito proxima certamente da idéia de que, para retomar a paráfrase bíblica, "o tempo se faz carne". A música é certamente a única manifestação que se faz carne no tempo e que faz do tempo, carne. Só que o tempo se faz também espaço com a música. É da música que determinamos as dimensões do tempo humano; é dela que nasce o tempo ordenado, encerrado e aberto em seu próprio fluir humano, enquanto sistematizado numa estrutura específica. Poder-se-ia pensar, quem sabe, nessa espacialização própria dos teatros, com as trompas wagnerianas a desenharem as encostas do Reno; ou a aparente simetria mozartiana a contornar o gesto precioso de Don Giovanni. São categorias espaciais e, por isso mesmo, pré-figurações das mãos e do contorcionismo facial do regente; ou do corpo do bailarino. Eles é que estimulam, pelo gesto, a música; e, pela música, o gesto.

Ocorre que nada tão relacionado com o tempo particular de quem escuta uma sinfonia, ou um samba, quanto a historia $\mathrm{em} \mathrm{si} \mathrm{mesma.} \mathrm{Por} \mathrm{essa} \mathrm{via,} \mathrm{pode-sc}$ discutir se "impressionismo" é a expressão mais correta para definir a música de Debussy, com seus acordes inconclusos que se fundem, no todo, como as pinceladas destacadas dos pintores do período, mas é difícil, senão impossível dissociá-la da arte dos artistas do fim do século na França, aqueles a quem a História irá chamar de "impressionistas" e que, por sua vez, não podem ser deslindados da literatura de um Proust (igualmente estillhaçada em processos narrativos quase que só pontilhísticos). Digamos que se a música é a carne do tempo, o tempo não deixa de ser a carne da música. Beethoven surpreendeu muito bem esse aspecto ao incluir na música a idéia de um pensamento acima da filosofia ou tão reveladora quanto. Por senti-la como carne do tempo, Beethoven definiu a música também por aquilo que ela poderia dizer sem afirmar nada.

Na Pastoral, a propósito, Beethoven fala explicitamente de uma música que não seria pintura, mas "sentimento" provocado pela imagem dos campos. Nada mais correto. Como já se mencionou, na música não há certamente idéias no sentido em que tais conceitos existam como num discurso filosófico ou político. Sob este ângulo, soa como uma ingenuidade puramente romântica a idéia, defendida por vários compositores da primeira metade do século, de que ao simples fluir musical qualquer um poderia deduzir a poeticidade de tal ou qual peça, descrevendo as respectivas situações. Mesmo nos melhores lieder de Schumann isso é quase impossível de descobrir: Heine são os seus poemas, não a música com que Schumann as transforma em canções no Diechterlicbe. Contudo, na música existem tanto as conseqüências das idéias quanto certamente o seu sentido não conceitual. Alguém falaria das razões que a própria razão desconhece. É um pouco também isso. 
Pois não parece haver dúvidas de que na música é possível surpreender uma ordenação do tempo que tanto se estriba nas premissas lógicas do discurso de um determinado período histórico quanto naquilo que, a rigor, está para além da simples paráfrase, mas que nem por isso perde a sua vigência enquanto pensamento. É o que anima as descrições musicais das do tipo que ofendiam a Hanslick e que vão culminar nos poemas sinfônicos como os de Strauss (que se pretende um "arcabouço" para certos programas); ou daqueles como os que fazem parte da literatura de um Thomas Mann, e de um Romain Rolland. Esses dois escritores, como se sabe (um com Doktor Faustus, outro com Jean Christophe) fizeram uma literatura recheada de alusões à música: não deixaram de tentar, em literatura, o que os músicos ensaiariam, à sua maneira, com os conceitos. Na apropriação de uma coisa ou de outra, músicos e escritores estariam colocando suas respectivas atividades nos termos de uma arte "total", naquilo em que Sófocles e Ésquilo teriam sido os precursores também dos operistas modernos (embora nada se saiba hoje das músicas que esses dois dramaturgos certamente usavam para suas peças teatrais). E que, em todo o caso, se constituíram no grande apanágio de Wagner.

Seja como for, é daí que vem a tal história: ninguém dirá de Mozart, só a partir de suas partituras, que pensava assim ou assado. Mas quando se fala de "música cortesã" fica implícito o que Mozart, Gluck e Haydn escreveram. Não foi por desprezarem a idéia de simetria, ou de uma bonomia, toda baseada em floreios e ornamentos, que a música de um ou de outro deixou de exprimir precisamente um mundo que exigia isso e que se expressava ideologicamente assim; e sempre como parte de um sucesso ideológico restritamente convencional, tal como certamente se exigiria de uma racionalidade historicamente comprometida com a ordem, toda ela expressa também no processo político. Deduzir de Mozart, ou de Haydn, que viviam num mundo convencionalmente elegante, por ser esse o primado da racionalidade hierarquizada, que via na "realeza iluminada" e bufante a fonte da boa política, não vai nenhum grande esforço de imaginaçăo. Assim também com as explosões revolucionárias de Beethoven. Parece mais do que obvio inferir de sua música o turbilhão provocado pela queda da Bastilha. Não são ilações que necessitem de quaisquer ensaios a respeito: a história as confirma.

Pareceria, pois, apenas um truísmo afirmar que a música enquanto carne do tempo é o seu arfar - que ela é os ventos e as brisas da História; e tudo por não ser conceito. Não se estranha, sobretudo, que todos a sintamos como um bafejo, um perfume que nos chega pesado de pressupostos que induzem a idéias. Por ser isso, porém, a música estaca precisamente nas idéias. Não há som musical que as expresse; existe, isso sim, uma expressão que se contrai e que arfa com a História e que, como no caso de Wagner (independentemente de seus libretos), pode influir decisivamente para a floração de algumas idéias; e que, antes dele, outros tantos, tais como Beethoven, tinham contribuído com o seu quinhão. Afinal, quando um Nietzsche admite a influência de Wagner, é de se perguntar o que fazem alguns de seus exegetas (principalmente brasileiros) quando mostram não ter a menor idéia do que seja a música wagneriana. Comparativamente, não há como se entender a omissão da música (ou da pintura, ou da literatura) nas aulas de História da maior parte das universidades de qualquer parte do mundo.

Em tudo isso, contudo e, forçosamente, a música ("a arte das musas", anotese) é a única que sai diretamente do poético e que, por ser o poético em si, não se 
faz conceito. ${ }^{1}$ Diria mesmo que ela antecipa-se a ele, fazendo-o apenas tempo na sua dimensão como tal, segundo uma relação que se estabelece entre as idéias, antes que elas próprias se "façam verbo", ou concomitantemente com ele. Otto Maria Carpeaux, em sua Nova História da Música, observa que Mozart conseguiu um tal milagre em sua obra, que, no Don Giovanni - especificamente na cena da serenata -, todos o descobriríamos mentindo; e apenas pela audição da mencionada ária. É uma conclusão forçada; mas Palestrina, ao praticamente eliminar certas dissonâncias, pode ter atraído para as idéias do Concílio de Trento bem mais que muitas pregações; e por pintar um mundo que, afinal, talvez repusesse o angelismo de que a Igreja necessitava naquele momento histórico. E se a contra-reforma irá aproveitar ou não esse processo, é outra discussão (não irá: o maneirismo e o barroco, pelo contrário, parecem ter incorporado a angústia da heterodoxia). Por essa razão, porém, a música também não é filosofia ou literatura, como queriam os compositores românticos, tais como Berlioz, Schumann, Liszt e outros. Para esses, o aforismo de Beethoven era incontestável; e tinham a confirmá-lo toda a música surgida principalmente da Revolução Francesa. Acreditava-se, em parte, no sortilégio do Le Chant du Départ de Méhul e na Marselhesa de Rouget de Lisle. Não eram elas as vozes recorrentes dos cantos das invencíveis tropas de Napoleão? Robespierre, em pessoa, não admitia que a música revolucionária podia tanto quanto as idéias? Sem dúvida, tais conclusões envelheceram. Mas, por não ser nem uma coisa nem outra, é iniludível que a música antecede aos conceitos como suspiro dos tempos - "saudades da História" - e não como sua verbalização, ainda que no caso da literatura, ou da poesia, essa dimensão musical seja alcançada exatamente no sentido inverso ao daquele que ela possa vir a ter. ${ }^{2}$

Tal fato tem a ver, significativamente, com o problema do propalado "atraso histórico" da música. De um lado, pode-se afirmar que, por não ser "teoria" e "reflexão" (a não ser em si mesma), a música se atrela a seu tempo bem mais que outras artes. Não deixa de ser verdade e a historiografia surpreendeu muito bem esse aspecto ao anotar alguns atrasos da música em relação a outras artes. Ao constatar que um gênio como J. S. Bach imiscuiu-se em seu século para muito além das formas que praticava (caídas em completo desuso, como a fuga), houve quem não apenas admitisse, mas afirmasse, como tese, o "atraso" fatal da música em relação às outras artes. Não é uma hipótese minimamente sustentável, mesmo se vista sob a ótica do progressismo historicista do século XIX. Bastaria atentar para o fato, também histórico, de que toda a arte é persistente no espaço e no tempo, independentemente das condições materiais da sociedade. Seria como não acatar o renitente classicismo greco-romano na escultura. E não é assim. Marx apontou muito bem para essa realidade.

Contudo, a música não deixa de ser, mais do que as outras artes, tempo do tempo. É tempo expresso como tal năo apenas para se definir a si mesma, mas também para se ter na temporalidade do ouvinte c na temporalidade da própria História. Por outra: a música é tempo por ser História, inclusive na sua imediaticidade. O romantismo é notável sob este aspecto.

Năo é uma falácia que Beethoven refletiu as angústias dos mortos das guerras napoleônicas, o heroísmo de um mundo conturbado pelas lutas revolucionárias e os confrontos entre as naçôes. Revoluções exigem empenhos ideológicos em vários níveis, razões para a vida e para a morte. Nunca se terá o que foi a Revolução Fran- 
cesa na subjetividade dos homens, feitos e auto-reconhecidamente, de um momento para o outro, iguais entre si. Todo o resto, inclusive, se pode depreender daí. Com a música não será diferente. Mas não o será em todos os quadrantes ou em todos os tempos. O caso brasileiro é bem significativo.

Não parece fortuito que um compositor brasileiro, o cearense acariocado Alberto Nepomuceno (1864-1920), fosse um lírico nas pegadas de uma sociedade bastante sofisticada, altamente repressiva no tempo e no espaço, mas resolutamente erótica em seus desejos raramente satisfeitos. Os processos eróticos do Brasil de antes da República são muito nítidos nas suas possibilidades, e devido, entre outros, a aproximações sempre tentadoras dos negros escravos que não precisavam (nem deviam) escamotear a sua sensualidade na luta pela sobrevivência. Concluir por aí que, em alguns casos, o decididamente erótico tanto da música de Nepomuceno quanto da pintura de Bernardelli é um dado do momento brasileiro parece apenas corroborar o que os romances de Machado de Assis, afinal, sempre expressaram.

Nessa linha, pode-se encontrar um equivalente em outro brasileiro: Villa-Lobos. É indiscutível que se trata de um criador anárquico; parece ser de seu temperamento a prolixidade esparramada, abundante, aliada à mais escarranchada necessidade de avançar sempre à frente como uma espécie de ânsia pelo fazer; mas se pode conjeturar que Villa esteja na ponta dos primórdios do industrialismo brasileiro, ou, quem sabe, que é o reflexo do primeiro impulso industrialista do "encilhamento": por produzir mais de mil obras, o compositor estaria se incorporando a uma idéia produtivista, não tão estranha, em síntese, a seu nacionalismo, ou mesmo ao seu positivismo. Tudo indica provir de Comte a idéia básica de Villa-Lobos de que a expressão de um momento dado deva ser elaborada sobre premissas ditas "científicas", Observe-se, neste sentido, que com todo o seu anarquismo, Villa-Lobos nunca irá descurar de dizer que fazia música como uma espécie de "mapa musical" de seu país. Comte foi o filósofo de maior vigência entre os intelectuais brasileiros da passagem do século. Daí a influir sobre um Villa-Lobos não vai uma distância muito grande. Quanto mais não seja, tendo em vista a sua colaboração com a idéia não de todo estranha a um certo "cientificismo" no didatismo do Estado Novo do ditador Getúlio Vargas. E, enfim, mutatis mutandis, qualquer semelhança ideológica com o húngaro Béla Bartók (cuja formação científica é um dado irretorquível) não parece ser uma conclusão apressada. Em qualquer lugar do Ocidente, alguns processos se dariam exatamente na mesma dimensão em que os homens os acataram; e também como parte da sua expressão artística. Mesmo aqui, pois, música e História andariam juntas.

Tudo isso é mais ou menos indiscutível. Na perspectiva desses artistas, a expressão seria um tempo específico nesta visão escancarada do momento histórico. $\mathrm{Na}$ forma contrária à de Descartes, talvez a pudéssemos definir num aforismo que se resumisse ao "existo, logo penso"; ou antes, ao "sinto, logo penso".

Mas não é só nessa dimensão que a música, enquanto tempo codificado, se faz um fluir também histórico. Talvez a questão mais ampla seja a de constatar que o tempo musical se constrói como História inclusive dos que não nasceram. Não seria apenas o tempo da História enquanto passado, mas o tempo da História como algo a ser feito. Refiro-me especificamente a essa História do devir que persistiria na música e que não nasceria de nenhuma adivinhação, mas de um envolvimento que se resolveria nas reflexões do futuro da música, como projeção de potencialida- 
des sociais. E como construções ideológicas bem nítidas. O mundo da polifonia não deixa, no fim das contas, de ser, no contraponto, uma idéia dialetal, de construção a partir do debate. Talvez, quem sabe, se pudesse deduzir desse fato o posterior democratismo que o protestantismo, sob o capitalismo emergente, irá desencadear como a própria forma, aliás, de manutenção do sistema. E, então, Bach seria um precursor também neste sentido (e não um artista "atrasado", como queriam alguns já aludidos historiadores do século passado). É possível. Mas é bem mais que uma possibilidade encontrar numa ou noutra obra de Beethoven a idéia fundamental de um mundo idealizado, tal como o projetou o revolucionarismo do período. E que, afinal, marca toda a sua obra, já que se trata certamente da expressão mais antropocêntrica que um homem projetou, desde a Renascença. Neste sentido, parece mais ou menos explicável que Mahler tivesse bem mais que idéias puramente musicais quando aconselhava a seus alunos que lessem Dostoiévski em vez de estudarem contraponto.

A pergunta que surge, portanto, pode ser nova: onde a relação dessa práxis, que é a própria música, e o envolvimento afetivo a que se referia Lênin e que preocupava Platâo - para só citar dois nomes? Há vários níveis de respostas possíveis, parece-me. A principal se prende à realidade da práxis. Por se realizar no tempo, o tempo da música é o do ouvinte. Por outra: nesse tempo não apenas se faz carne no sentido em que a música alicia; deve-se considerar que realiza este seu objetivo como um processo de sua própria natureza de práxis. Se o tempo da música é o tempo do ouvinte, a música só é práxis por só poder ser enquanto ação no tempo presente. Logo, não há alternativa para o ouvinte como tal: ao escutar uma música, ao realizá-la em sua memoria e na imediatidade desse processo, o melômano faz do seu o tempo que the está fora; e é nesta perspectiva que não há escolha possivel. Isto é, ou o ouvinte como que "corporifica" os sons que the são exteriores, ou então a música não se "faz" para ele.

A este respeito Wagner fez, certa vez, uma confissão, quando menos, instrutiva. Dizia ele que só foi entender a nona sinfonia de Beethoven quando a ouviu sendo executada por Habeneck, regente da orquestra do Conservatório de Paris. Não foi pela partitura que Wagner - um leitor, de resto, presumivelmente competente acabou chegando às "verdadeiras" intenções de Beethoven, mas à sua práxis, à sua execução. É significativo.

Realmente, a música não existe para além do ouvido de quem a escuta. Uma música pode ser apenas para seu intérprete; ela pode inexistir para quem não aprecia este ou aquele gênero; mas, a rigor, ela não se realiza sem a ressonância direta de alguém que a faça, tanto no gesto de sua concretização ativa quanto no ato de escutar - o que, em última análise, redunda no mesmo. E, embora existam diferenças entre o ato de "fazer a música" como intenta o intérprete e o processo de construí-la como faz o ouvinte, há sempre, em qualquer condição, uma construção real, tanto de parte do instrumentista quanto de quem a escuta.

Nestes limites e de qualquer modo, o que se verifica é uma interação de tempos. É como se o ouvinte (ou o intérprete, isso não importa) efetivamente "incorporasse" a música para que ela se fizesse o tempo de quem a escuta. ${ }^{3}$

E, na realidade, é isso mesmo que ocorre. Ao se "fazer" Beethoven, o ouvinte que presta a sua atenção à quinta sinfonia, em Dó menor, recolhe-se a sua alteridade para se tornar um pouco o "tempo" de Beethoven, isto é, também o momento 
histórico que o compositor estratificou a seu modo. É neste sentido que a música se faz tempo para ser a subjetividade do outro. É aqui que valem as palavras de Hegel sobre a música, como sendo "a última instância do subjetivo". A música é isso, não há o que discutir. Mas o é por ser um arrebatamento do homem no âmago de sua historicidade e, portanto, por ser práxis na subjetividade radical; ou seja, por ser um fazer-se que só envolve e é envolvido, e porque o envolver é da propria essência do tempo: ao assumir o momento do ouvinte, a música faz-se no ouvinte e o ouvinte se faz no tempo da música. Seriam esses os níveis dessa "incorporação" ou, se quisermos, desse aliciamento que tanta desconfiança vem suscitando ao longo dos séculos.

Por tudo isso caberia, como sempre, um retorno aos gregos. Poder-se-ia talvez indagar, de novo e com razão, sobre a suspeita que Platão e outros filósofos mantiveram em relação à música. E talvez devêssemos vislumbrar na teoria musical da civilização helênica apenas um espanto, uma espécie de inconformidade com o fado irresistível da música. É evidente que ao elaborarem um esquema sobre os desejos que a música podia provocar, os gregos não a estavam inquirindo na sua realidade completa.

É ao que nos remete o mito do canto da sereia da Odisséia: enquanto a escuta, Ulisses se deixa arrebatar; seu tempo se conforma com o das sereias; mas tal qual um enigma que não pode ser questionado, nem Ulisses nem Platâo (nem outro grego qualquer, diga-se) tentaram atinar sobre o porquê de tal sortilégio. Haveria, no entanto, que fazer exatamente isso. Os gregos, mais que todos os povos, parecem ter tido uma real necessidade de reduzirem toda práxis à racionalidade; desde que, no caso da música, a questão ficou relegada ao mito, não estranha que a tradição filosofica ocidental não se tivesse manifestado a respeito da mesma forma com que outras artes foram investigadas.

Seja como for, o que fica de forma muito clara é que, no medo do canto da sereia (e no canto da sereia parece residir exatamente o sortilégio "invencível" da música, para os gregos), revela-se a impossibilidade do pensamento helênico de descobrir na música tanto a práxis quanto o logos fazendo-se verdade na sua própria realização. ${ }^{4}$

Claro, talvez se devesse adużir que, por ser práxis, o iogos da musica seja a sua ação, vale dizer, o tempo - única estrutura com a qual podemos inquiri-la. Certamente. E não apenas no sentido de que a música se faz o tempo do ouvinte no torpor a que certas músicas o submetem (lembro o rock e algumas obras renascentistas), mas nesta concepção em que a obra musical, seja ela qual for, será sempre a invasão de um instante no corpo/tempo do ouvinte. Não é o que acontece com as outras artes. Posso me deixar envolver por um poema; sua musicalidade pode me submeter e os conceitos que se fazem na másica podem me dar, do poema, a sua estrutura enquanto tempo - mas não é a única de que se vale a poesia, cujo suporte, evidentemente, não é o tempo strictu sensu.

Pois bem, já me referi ao "tempo cardíaco" a que a música se conforma. É assim mesmo. Ao surpreender o melômano em seu instante, para estigmatizá-lo com um tempo que se faz um só - o da música propriamente dita tornada, agora, instante do ouvinte -, não existem alternativas possíveis fora do arrebatamento, da entrega total.

Conta-se, a propósito, que um dos ouvintes da estréia da Sagração da Primavera, de Stravinsky, em 1913 (apresentação que suscitou uma das maiores reaçōes de 
que se tem notícia), só percebeu que estava sendo agredido, literalmente golpeado por um outro ouvinte, tão nervoso quanto ele - e também "tomado" pela excitação da música -, quando, ao se sentir incomodado, surpreendeu um homem a socá-lo, por trás. Antes, o citado ouvinte só sentira "um certo mal-estar".

A ser verdade essa historia, temos aí um exemplo extremo. Mas não é por qualquer casualidade, parece, que os ritos hipnóticos (ao qual estão associados espetáculos de grandes massas, como os concertos de rock) devam ser sempre amplificados e exatamente para se imporem como tais; assim como não parece por uma mera circunstância que determinados ritmos, inclusive os usados por algumas religióes, sejam adotados para celebraçôes que visam única e exclusivamente a uma certa hipnose. É como se a perda do "ego" se desse para muito além da "tomada" da música apenas pelo "coração" e que, ao ser absolutamente "corporificado" pelo processo dessa "alteridade", se operasse uma despersonalização, de modo a que o "eu" se esvaísse no fluir musical.

Aqui talvez valessem algumas outras considerações. Aludi acima ao rock e à música amplificada. É iniludível que a sua gênese está nesta sua origem talvez onírica. A redução dos ritmos ao primarismo do dois por quatro, na quase subjugação ao batimento cardíaco, parece impor que o que está sendo ouvido não seja contestado. O "totalitarismo" a que se referia Theodor W. Adorno, na verdade, parece estar hoje em seu pleno fastígio. A começar exatamente pelo volume exigido para a audição de certas músicas. Impossível fugir delas; inútil ignorá-las enquanto em seu raio de ação. Inimaginável, portanto, furtar-se a seu "sortilégio".

Seria esse o retorno ao feitiço das sereias a arrebatarem os homens numa experiência em que a "cera nas orelhas" (com que Ulisses protegeu seus marinheiros) não se constitui mais numa possibilidade, na medida mesmo em que os ouvidos não têm como fugir à ditadura de uma música que invade a totalidade da vida humana? A resposta parece clara. Mesmo porque o "escutar" passa a ser um ato voluntário do ouvinte quase que apenas no recesso de um teatro de música de concerto, ou diante do chamado aparelho de som. No mais, parece não haver volição alguma: o que comanda o mundo são as caixas de som com a sua capacidade de impor ao ouvinte o que se bem entender.

$O$ assunto vai longe. E o romantismo parece ter precedido essa ação: foi quando hauriu dos tempos e da história da época (na qual estão envolvidas as guerras napoleônicas, as revoluções nacionalistas e a autogestão nas idéias democráticas) a possibilidade de interiorizaçẵo de algumas reflexões, exatamente no coração de suas virtualidades. É neste instante, na verdade, que a música se torna "filosofia", consoante o pensamento de Beethoven: o romantismo introjetou a realidade como uma totalidade, na admissão de que o "sentir" era a única alternativa de um tempo em que, nos seus antípodas, o conservadorismo considerava a subjetividade como uma imoralidade - um despuđoramento. O salto do romantismo em relação ao período "clássico" (como o barroco em face da música renascentista nas fórmulas da escola de Palestrina) é que, nesse, a racionalidade impóe à música uma peia que o romantismo irá repudiar; e não apenas por fazer uma nova música, mas por expressar a musicalidade dos novos tempos, onde os homens, pelo menos teoricamente, podem se autodeterminar num processo em que, conforme alguns princípios da Revolução France$\mathrm{sa}$, todos encontram-se diante da perspectiva de screm "iguais entre $\mathrm{si}^{\mathrm{i}} .^{5}$ 
Com efeito, ao fazer da subjetividade a idéia-força do período romântico, os músicos que se seguem a Beethoven incorporaram à música a maior contribuição que os tempos poderiam legar à História - seriam os primeiros a fazer da música a expressão da práxis revolucionária. Os fatos o demonstram.

Ao que consta, a Marselhesa só voltou a ser cantada pelas tropas de Napoleão (que, por sinal, não apreciava o hino de Rouget de Lisle) após a grande vitória de Austerlitz. Mas antes disso, já a Marselhesa tinha dado o tom das lutas revolucionárias. ${ }^{6}$ A música impunha o tônus de vida como provavelmente nunca antes na História. Pode-se admitir, ainda dentro deste tema, que ao constituir orquestras com centenas de instrumentistas, Hector Berlioz tenha expressado, na música de concerto, todo um passado imediato, já que Gossec, Grétry e especialmente Le Sueur (seu professor) tinham procedido da mesma forma. Mas não é um despropósito, parece, pensar que o músico francês foi um dos primeiros a tentar a "musicalização" do mundo como forma de expressão daquela "última instância" da subjetividade, cantada em prosa e verso pelos defensores do "mal du siècle" como a derradeira realidade a ser comentada.

Sem embargo, a grande orquestra, aquela que já tinha sido ensaiada nos tempos de Haendel (que chegou a reunir em alguns eventos várias centenas de músicos, como aconteceu em alguns dos festivais organizados na Inglaterra), só foi se constituir na sua formação atual - com quase uma centena de músicos, em média - a partir da Revolução Francesa; ou, mais precisamente, do romantismo como um todo. Um fato, de qualquer maneira, é inegável: o agigantamento da orquestra sinfônica corresponde à ampliação dos seus ouvintes e à realidade de que os conjuntos sinfônicos só poderiam ser ouvidos ao ar livre, onde cabiam mais pessoas, se multiplicados (ainda que, como concluiu empiricamente Berlioz, a duplicação ou a triplicação dos instrumentos nấo redundassem na duplicação ou triplicação do volume do som). Logo, não parece especioso deduzir que essa ampliação se dará em decorrência da democratização política. Mas é claro também que a recíproca pode ser verdadeira. Não foi apenas o democratismo da música a única expressão da democracia foi também a música como expressão do mundo que referendou o democratismo. Não soa estranho ao raciocínio de um Beethoven que a sua música devesse ser revelada a muitos e não por sẹrem muitos (os "milhões" de que falam os versos de Schiller e que ele usaria na nona sinfonia em Ré menor), mas porque sua música se constituiria, afinal, numa "revelação". Daí e por isso a ampliação da orquestra (e não apenas a de Beethoven, evidentemente). Mas daí também a ampliação do espectro do som até a sua "ditadura" atual, em que a amplificação é consentânea com as tentativas de fazer da música o ambiente natural do mundo.

E pode parecer uma mera extrapolação, mas a musak, essa música entreouvida em banheiros de aeroportos, bares e lojas, feita para não ser fruída, rigorosa e paradoxalmente, parece provir de Beethoven e dos músicos da Revolução Francesa. O raciocínio não estaria, em verdade, muito distante do que dissemos no princípio sobre a relação da música com o seu mundo e com a própria idéia da práxis como expressão e criação do cosmos. Dito de outra maneira: nos extremos de tal raciocínio, não se afigura como um exagero, por exemplo, encarar nas intenções da sinfonia número oito, a "dos mil", de Gustav Mahler, aquilo que os modernos aparelhos de som conseguiram conquistar com a quadrifonização. Ao concebcr uma obra em que os músicos literalmente "ocupam" um teatro, Mahler não deve ter pensado em 
menos do que na musicalização do mundo, ou, se quisermos, na conquista do mundo pela música; seria como alcançar o mundo pela música e vice-versa. Mas seria possível pensar em tal, sem ter em vista a interferência da indústria, como afinal acabaria ocorrendo? Seria evitável a musak, uma música que, ao ser concebida, terá por princípio exatamente a não-interferência nos corações e mentes dos ouvintes? A resposta parece transparente. E pode-se culpar ao tempo resgatado da produção o teor censurável que a grande música assume, por ocupar o tempo do ouvinte nas sociedades altamente produtivas; o que não se pode, em suma, é acusar a música essa música alienante - de não ser, no fim das contas, o ápice de um grande processo; e no qual o processo musical não apenas entra como expressão, mas também como co-partícipe da História na marcha para a sua dissolução.

Pois é disso que se trata quando se pensa numa pós-modernidade que não apenas quer o fim da música, mas, et pour cause, a dissolução da História. Ora, o que se pode contrapor a isso não se dissocia da questão do mundo pensado como música e da música pensada como mundo. Será na práxis, na atividade musical instaurada como reflexo da ação transformadora que a música encontrará a sua solução. $E$ não será menos que a solução também do mundo. Pelo menos do mundo como ele é; e que a música ajudou a construir.

Sob este aspecto - e cabe realmente a conclusão - Pitágoras, no fundo, estava certo: o mundo como música pode não ser (e não é) mais que o mundo como literatura ou como ciência. Mas História e música marcham juntas no suporte do tempo. Não é pouco se considerarmos a música como a "poética" da historicidade. Com o quê, uma seria corolário da outra. Como certamente queria Pitágoras.

\section{Notas e Referências}

1. A palavra vate, como sinônimo de poeta, tem muito a ver com essa ordem profética da poesia. $\mathrm{O}$ poeta, como o homem que "faz vaticínio" (ou seja, o vate), é a expressão maior de um sortilégio que a tradição ocidental atribuiu aos poetas e que certamente se aplica à música pela simples razão da sua origem etimológica, ou da sua pretensão de ser, rigorosamente, a arte dos que geram os vates - vale dizcr, "das musas", as inspiradoras de todos os poetas. Rousseau lembra, a este respeito, residir não na necessidade, mas no afeto "não-racional" a causa primeva de todas as línguas (In: A Origem das Línguas, ed. Abril). Daí ao sortilégio próprio de uma expressão que adviria dos vates (confundindo com um poder de premonição) vai uma distância razoável. E vai também a confusão definitiva: de uma arte que apenas se propõe a sugerir - muito aquém (ou além) das "impressões" que possam nascer da palavra poética - é de praxe que fique num terreno movediço. E explica-se que os filósofos, de uma maneira geral, sempre sentissem o grande problema da música precisamente nesta dimensão de ser indizível. Seria pela música que o homem se voltaria à noite, de seu inconsciente, de suas paixões. Jorge Luis Borges, no seu El Informe de Brodie, roça a questäo ao contar a história de um povo que apedrejava seus poetas por se sentir emocionado por eles. Assim também, nos limites da reflexão sobre essa indizibilidade da música, restaria a interpretação sobre a sua nebulosidade - aquele ambiente em que os vates realizavam suas profecias e que, na música, seriam tão-somente nebulosidade, meros sentimentos, sensações ou sugestões, como se queira, já que sequer ela se valeria dos conceitos... (N.A.)

2. Gerd Bornheim, in: Metatisica e Finitude. Ed. Movimento, Porto Alegre.

3. A idéia de "incorporação" que se expressa nos ritos afrobrasileiros é determinada pelo ritmo e pela melodia dos "pontos". Não há exemplo mais radical em que a música se "corporifica", ainda que, no caso, um umbandista dirá que a música é apenas uma intermediação ou, como ocorre com o receptor do santo, aquilo que normalmente na linguagem das religiōes afrobrasileiras é chamado de "cavalo".

4. Anote-se, de passagem, que a mitologia acolhe esse sortilégio "invencível"; é graças a sua música que Orfeu consegue mudar, por instantes, o sentido do inclutável da morte. Ao descer aos infernos em bus- 
ca de Eurídice, o cantor e poeta realiza o feito impensável de arrostar a própria morte ditada pelo fado e contra o qual, aliás, nada podem nem mesmo os deuses. Orfeu faiha, como era previsto. Mas sua façanha - que, no fundo, é a façanha da sua música -, se não logra obter a vida de Eurídice de volta, remete à lição dúbia: de tão insidiosa, ou de tão "mágica", eis que a música, por instantes, obnubila os próprios designios irredutiveis. E engana, ou ilude, por instantes, por ser de sua natureza fazê-lo assim, já que trabalha com instantes. E tudo isso, enfim, não é um tema estranho aos alemães e, em particular, a uma figura como Wagner. Pois a idéia de uma cultura que se faz pela "sugestāo" da música, vale dizer, por seu "sortilégio", mais que um tema, parece ser um paradigma: talvez seja essa a questão a ser discutida tanto a propósito do pensamento alemão quanto pela realidade de que esse pensamento nunca ficou (nem poderia ficar) isento da influência da música.

5. A idéia de um autodesnudamento parece encontrar guarida nos precursores do romantismo. Rousseau escreverá suas "Confissões", que provocaram reações certamente por seu aspecto confessional; Beethoven, leitor de Rousseau, mencionará suas "impressões" a respeito do campo na sinfonia Pastoral, e Grétry, espécie de alter ego musical de Rousseau, durante a Revolução Francesa, escreverá sobre "seu mundo" e "sua música" com a convicção de que tem muito a dizer. Ou seja, Chopin e sua arte subjetiva (Otto Maria Carpeaux falará, com razão, de uma "arte esotérica") não chegarão muito depois desses cometimentos. $O$ interessante, entretanto, é que o "desnudamento" do ego se dará em concomitância com o desnudamento real dos corpos: os vestidos transparentes que se irão impor à Europa fazem parte do repertório da Revolução e do Império Napoleônico, tanto quanto as idéias de liberdade, igualdade e fraternidade. 6. E não apenas da revolução em si, mas da vivência que ela imporá à Europa toda. Como informa Romain Rolland (Beethoven, ed. Cosmos, Lisboa), já em 1892 a Marselhesa era tocada nos cafés alemães e, óbvio, como "música de salão".

\section{Enio Squeff é jornalista e crítico de música.}

